\title{
Isolation of Microorganisms and Development of Microbial Augmentation for Treatment of Paper Mill Wastewater
}

\author{
Dae Ook Kang ${ }^{2}$ and Hyun-Hyo Suh ${ }^{1}$ *
}

${ }^{1}$ Department of Environmental Engineering, Gyeongnam National University of Science and Technology, Jinju 660-758, Korea

${ }^{2}$ Department of Biochemistry and Health Science, Changwon National University, Changwon 641-773, Korea

Received January 17, 2011 /Accepted January 20, 2011

\begin{abstract}
This study was performed to investigate the effects of microbial augmentation on the biological treatment of paper mill wastewater. Three bacteria (KN11, KN13, KN27) capable of degrading aromatic compounds and a bacterial strain (GT21) producing an extracellular cellulase were isolated from soil and wastewater by selective enrichment culture. Through morphological, physiological, and biochemical taxonomies, isolated strains of KN11, KN13, KN27, and GT21 were identified as Acinetobacter sp., Neisseria sp., Bacillus sp., and Pseudomonas sp. and named Acinetobacter sp. KN11, Neisseria sp. KN13, Bacillus sp. KN27, and Pseudomonas sp. GT21, respectively. For analysis of non-biodegradable and chemical oxygen demand (COD)-increasing matter in a paper mill wastewater, we utilized GC/MS to detect aromatic compounds and their derivatives containing several substituted functional groups. The microbial augmentation, J30 formulated with the mixture of bacteria including Acinetobacter sp. KN11, Neisseria sp. KN13, Bacillus sp. KN27, and Pseudomonas sp. GT21, was used for the treatment of paper mill wastewater. The optimum temperature and $\mathrm{pH}$ for COD removal of the microbial augmentation, J30, were $30^{\circ} \mathrm{C}$ and 7.5 , respectively. For evaluation of the industrial applicability of the microbial augmentation, J30 in the pilot test, treatment efficiency was examined using paper mill wastewater. The microbial augmentation, J30, showed a COD removal rate of $87 \%$. On the basis of the above results, we designed the wastewater treatment process of the activated sludge system.
\end{abstract}

Key words : Mircobial augmentation, chemical oxygen demand, wastewater treatment, pilot test

\section{서 론}

오늘날 산업의 발달과 함께 제품의 생산이 다양화됨에 따라 환경오염이 점점 심각한 문제로 대두되고 있으며, 폐수처리에 있어서 폐수 속의 난분해성 및 독성 물질의 유입으로 처리에 많은 어려움이 발생되고 있다[11]. 펄프 및 제지공업 폐수의 국내 발생량은 국내 산업폐수 발생량의 약 $9 \%$ 를 차지하고 있 으며 수계의 폐수 방류량은 섬유공업 다음으로 많은 폐수 발 생량을 나타내고 있다. 현재 우리나라의 경우 대부분의 제지 회사들은 외국에서 펄프나 고지를 수입하여 쓰거나 약간의 쇄목펄프(ground pulp)를 생산하여 종이 원료로 사용하고 있 다. 제지산업에서는 목재에 포함된 cellulose를 분리하여 펄프 를 생산하고 이것을 가공하여 여러 종류의 종이를 만들며 목 재에는 lignin이 $25 \%$ 정도 들어있다[11].

펄프 및 제지폐수의 처리는 대부분 물리화학적 처리와 생물 학적 처리를 병행하고 있으며 폐수처리 공정 전 단계에 부유 고형물의 제거를 위한 응집침전 혹은 가압부상 방식의 물리화 학적 처리를 채택하고 있다. 현재 국내의 펄프생산은 일부 회

\section{*Corresponding author}

Tel : +82-55-751-3340, Fax : +82-55-751-3484

E-mail : hhsuh@gntech.ac.kr
사에 한정되어 있어 폐수의 발생량은 극히 미미한 실정이며 국내에서의 펄프 및 제지폐수는 대부분 제지폐수에 한정되어 있다[10,11]. 펄프의 가공에서 시작되는 제지폐수는 생산지종 에 따라 다양한 화학물질이 사용되고 있어서 폐수의 성상도 수시로 변한다. 제지폐수의 생물학적 처리 시 다양한 폐수 성 상과 부하 변동으로 인한 활성오니의 충격현상, 처리율 감소 와 침전불량의 벌킹현상 등 많은 문제점이 나타나고 있다. 이 러한 문제점으로 인해 제지폐수에는 lignin과 같은 난분해성 물질, 분산제, 형광 표백제와 계면활성제 등이 포함되어 있어 생물학적 처리에서 발생되는 문제의 원인이 되고 있다 $[1,10,17]$.

현재 제지폐수의 생물학적 처리에서 발생되는 문제의 해결 을 위해 여러 가지 연구가 시도되고 있으나 대부분 독성물질 즉, chlorinated phenols과 같은 물질분해에 관한 연구가 주류 를 이루고 있으며 복합물질이 함유된 폐수의 전체적인 처리효 율을 증진시키기 위하여 RBC 생물막의 이용과 같은 처리공법 을 달리하는 연구가 진행되고 있다[9,19]. 최근에 제지폐수의 생물학적 처리에 발생되는 문제해결을 위하여 미생물을 이용 한 폐수처리공법이 활발히 연구되고 있으며 특히, 난분해성 물질과 독성 물질의 분해를 촉진시키기 위하여 미생물을 이용 한 연구가 진행되고 있다 $[5,14,21]$. 이러한 시도의 일환으로서 
유용 미생물을 대량 배양하여 미생물 제제라는 이름으로 상품 화시켜 시중에 유통되고 있으나 이들 미생물 제제에 대한 사 회적 인식이 확립되지 않았을 뿐 아니라, 적절한 판단기준이 나 평가기준이 없는 점은 각 폐수처리장에서 미생물 제제의 일반적인 사용의 문제점으로 인식되고 있다.

본 연구에서는 제지폐수 속에 존재하며 다양한 오염원인 난분해성 물질 및 독성 물질의 분해능이 우수한 미생물을 분 리하여 제지 폐수처리에 적합한 미생물 제제를 개발하고 이를 이용한 제지폐수의 처리에 미치는 영향 및 특성에 대하여 조 사하였다.

\section{재료 및 방법}

\section{폐수시료의 선정}

본 연구에 사용된 폐수시료는 경남 소재의 J 제지공장의 원수, 1 차 처리 수, 폭기조, 침전조와 방류수를 대상 제지폐수 로 선정하였고, 이들 폐수의 성상은 환경오염 공정시험법과 standard method [4]를 이용하여 분석하였다.

\section{방향족 화합물 분해균주의 분리}

Benzene과 phenol 등 방향족 화합물 분해 균주의 분리는 전국 각지에서 채집한 폐수와 토양을 균주원 시료로 하여 멸 균된 증류수로 연속 희석한 후 희석액을 $\mathrm{LB}$ 평판 고체배지에 도말하여 나타난 집락(colony)을 tooth-pick로써 고체 최소배 지에 접종하고 benzene과 phenol을 각각 증기상태로 공급하 면서 $25^{\circ} \mathrm{C}$ 에서 약 5 일간 배양한 후 집락을 관찰하여 자화능이 우수한 균주를 분리하였다. 미생물 배양 및 특성 조사를 위하 여 사용한 배지는 고 등[13]이 사용한 최소배지를 사용하였으 며, 배지 11 당 각 성분의 조성과 함량은 $\mathrm{NH}_{4} \mathrm{Cl} 1.0 \mathrm{~g}, \mathrm{~K}_{2} \mathrm{HPO}_{4}$ $4.35 \mathrm{~g}, \mathrm{NaH}_{2} \mathrm{PO}_{4} 3.9 \mathrm{~g}, \mathrm{MgSO}_{4} \cdot 7 \mathrm{H}_{2} \mathrm{O} 0.48 \mathrm{~g} \mathrm{CaCl}_{2} 0.03 \mathrm{~g}$, $\mathrm{FeSO}_{4} 0.01 \mathrm{~g}, \mathrm{MnCl}_{2} 0.01 \mathrm{~g}, \mathrm{CoCl}_{2} 0.001 \mathrm{~g}, \mathrm{Na}_{2} \mathrm{MnO}_{4} 0.001$ $\mathrm{g}$ 등이며 $\mathrm{pH}$ 를 6.8 로 조절하였다.

\section{Cellulose 분해균주의 분리}

제지폐수의 주성분인 cellulose를 분해시킬 수 있는 미생물 을 분리하기 위하여 경남, 전남, 부산 일원의 토양, 톱밥퇴비 및 썩은 볏집 등에서 채취한 시료를 생리식염수로 $10^{-3} \sim 10^{-6}$ 으 로 희석하여 분리용 고체배지에서 상기 시료의 현탁액을 도말 하여 배양한 후 $0.1 \%$ congo red 용액으로 30 분간 염색하고 $1.0 \mathrm{M} \mathrm{NaCl}$ 용액으로 세척하여 clear zone의 형성 유무를 확 인하였다[26]. 손 등[22]의 방법을 변형한 분리용 고체배지는 멸균된 생리식염수 11 에 carboxlymethyl cellulose $5 \mathrm{~g}$, $\left(\mathrm{NH}_{4}\right)_{2} \mathrm{SO}_{4} 2.5 \mathrm{~g}, \mathrm{~K}_{2} \mathrm{HPO}_{4} 0.25 \mathrm{~g}, \mathrm{MgSO}_{4} \cdot 7 \mathrm{H}_{2} \mathrm{O} 0.1 \mathrm{~g}, \mathrm{FeSO}_{4}$. $7 \mathrm{H}_{2} \mathrm{O} 0.002 \mathrm{~g}, \mathrm{MnSO}_{4} \cdot 4 \mathrm{H}_{2} \mathrm{O} 0.002 \mathrm{~g}, \mathrm{NaCl} 0.1 \mathrm{~g}$, yeast extract $1.0 \mathrm{~g}$, trypan blue $0.25 \%$ solution $(0.66 \mathrm{ml} / 100 \mathrm{ml}$ medium) 등으로 구성되었으며, cellulose 분해균주 배양조건은
$\mathrm{pH} 7.0,30^{\circ} \mathrm{C}$ 에서 5 일간 배양하여 clear zone 형성이 큰 균주를 선별하여 이를 제지폐수 처리용 미생물로 활용하였다.

\section{분리균주의 동정 및 보존}

분리균주의 형태적, 생리적 그리고 생화학적 특징을 조사한 후 Bergey's manual of determinative bacteriology [20]와 manual for the identification of medical bacteria (2nd ed) [16]에 따라서 균주 동정을 실시하였다. 각 균주의 DNA 염기 조성 $(\mathrm{G}+\mathrm{C}$ 함량)은 Tamaoka와 Komagata [24]의 방법에 따라 reversed-phase HPLC에 의해 분석하였다. 분리균주는 최소 배지에 계대배양하여 보존하였고, 또한 ampoule에 동결 건조 하여 보관하였다.

\section{미생물제제의 제조}

처리대상 폐수와 경남, 전남, 부산 일원의 토양 및 폐수로부 터 분리된 120 주의 균주 중 유기물 및 난분해성 물질 분해능이 높고, 균체 증식속도가 빠른 Pseudomonas sp. KN11, Neisseria sp. KN13 균주와 Bacillus sp. KN27 균주 외에 cellulose 분해균 주 Acinetobacter sp. GT21 균주를 첨가하여 제지폐수 처리용 미생물제제로 사용하였고 이를 J30으로 명명하였다. 제지폐수 처리용 미생물 제제 J30의 미생물 재현성을 확인하기 위하여 plate count agar (PCA) 배지 상에서 보존 기간별로 도말하여 균체의 생존능을 검정하였다.

\section{폐수의 기초성상 분석 및 호흡률 조사}

대상폐수의 총 유기탄소 농도는 TOC analyzer (DoHrmann DC-180, 나라)로 분석하였으며, biological oxygen demand $(\mathrm{BOD}), \mathrm{COD}_{\mathrm{Mn}} \mathrm{COD}_{\mathrm{Cr}}$, 총 질소함량( $\left.\mathrm{T}-\mathrm{N}\right)$ 및 총 인함량(T-P) 등은 수질오염공정시험법과 standard method [4]에 준하여 분석하였다.

폐수처리장 내 각 공정상의 원수, 1 차 처리 수, 폭기조에서 채취한 시료를 폭기조 내 생물량을 기준으로 이들의 호흡에 영향을 미치는 원인인자를 조사하기 위하여 산소소모율을 조 사하였으며, 단위 시간당 소비되는 산소 농도를 측정하여 폐 수에 대한 미생물의 호흡률을 계산하였다.

$$
\begin{aligned}
& \text { 산소 소비율 }=\frac{D O i-D O e}{M L V S S \times T} \times 60 \\
& D O i: \mathrm{t}=0 \text { 에서의 포화산소 농도 } \\
& D O e: \mathrm{t}=\mathrm{t} \text { 에서의 산소 농도 } \\
& M L V S S: \text { 슬러지 휘발성 고형분 농도 } \\
& T: \text { 실험시간(time) }
\end{aligned}
$$

\section{GC/MS 분석}

제지폐수에 함유되어 있는 난분해성 물질의 유도산물 및 $\mathrm{COD}$ 증가의 원인 물질을 분석하기 위하여 폐수 시료를 gas 
chromatography (GC)와 mass spectrometer (MS)를 이용하여 분석하였다.

\section{처리효율 시험}

제지폐수처리 시험을 위한 실험실 규모의 반응조는 활성오 니공정과 접촉산화식공정을 병행하여 운전할 수 있도록 설계 하였다. 실험실 규모의 장치는 용량 21 의 투명 아크릴판을 이용하여 제작하였으며, 공기는 반응조의 바닥에 산기석을 설 치하고 air blower에 연결하여 폭기 하였다. 반응조 내에 DO 농도는 air blower를 조절하여 2 3 mg/l, 온도는 자동조절기 를 이용하여 $25 \pm 2^{\circ} \mathrm{C}$, 그리고 수리학적 체류시간(HRT)은 48 $\mathrm{hr}$ 으로 유지하였으며 $\mathrm{pH}$ 는 7.5로 조절하였다.

\section{결과 및 고찰}

\section{미생물제제 제조를 위한 균주의 분리}

Benzene과 phenol 등의 난분해성 방향족 화합물 분해균주 는 전국 각지의 토양, 폐수 등에서 분리한 120 균주 중 방향족 화합물의 분해 활성이 우수한 균주를 선별하였다. 1차 선별은 방향족 화합물을 증기상으로 공급하면서 $30^{\circ} \mathrm{C}$ 에서 5 일간 고 체배양 하였을 때 세균 집락 형성능이 뛰어난 균주를 선별하 였으며, 이들 균주 중 방향족 화합물을 공급한 액체 최소배지 에서 방향족 화합물 자화능이 우수한 균주 $\mathrm{KN} 11, \mathrm{KN} 13$, $\mathrm{KN} 27$ 균주를 최종 선별하였으며, 이들 분리균주들은 방향족 화합물뿐만 아니라 일반 유기물 분해활성도 뛰어난 것으로 확인되었다.

또한 제지폐수의 주성분인 cellulose를 분해하는 균주를 선 별하기 위하여 균주원 시료로부터 분리된 70여 균주 중 cellulose 고체배지 상에서 clear zone 형성능이 높은 균주들을 선별 하였으며 이들 분리균주 중 cellulose 분해활성이 가장 큰 GT21 균주를 최종 선별하여 본 연구에 사용하였다.

\section{분리균주의 동정}

분리 균주의 동정을 위하여 형태학적, 생리학적, 생화학적 특성을 조사하였다(Table 1). 분리균주 KN11은 Gram 음성 간 균으로서 운동성을 지니고 있었다. Catalase 양성, oxidase 음 성으로 glucose에서 산을 형성하지 못하였고, nitrate, VP test 에서 음성반응이었으며 indole test는 양성을 나타내었다. $\mathrm{DNA}$ 염기 성분인 $\mathrm{G}+\mathrm{C}$ 함량은 $39 \%$ 를 나타내어 Acinetobacter $\mathrm{sp}$. 의 $\mathrm{G}+\mathrm{C}$ 함량[23]과 거의 일치하였다.

그리고 분리균주 $\mathrm{KN} 13$ 은 Gram 음성 구균으로서 크기는 $0.7 \mu \mathrm{m}$ 이었고 포자 형성능과 운동성이 없었다. Catalase와 oxidase를 생성하였고 Voges-Proskauer (VP) test와 indole test 에서는 음성이었고 nitrate test에서는 양성을 나타내었다. Glucose를 제외한 나머지 탄소원에서는 산을 생성하지 못하 였고 G+C 함량은 $52 \%$ 였다. 이러한 특징은 Neisseria sp. 과
유사한 것으로 나타났다. 분리 균주 $\mathrm{KN} 27$ 의 경우 Gram 음성 의 간균으로서 포자 형성능과 운동성을 지니고 있었다. 집락 의 색깔은 milky-white를 띄었고 호기성 상태에서 생육하였 다. Catalase test와 oxidase test에서 모두 양성반응을 나타내 었고 glucose, lactose, sucrose와 xylose에서 산을 생성하였다. 또한 gelatin과 starch를 잘 분해하였으며 VP test에서는 음성 을 나타내었으며 $\mathrm{G}+\mathrm{C}$ 함량은 $46 \%$ 를 나타내었으며, 이러한 결과는 Bacillus sp.과 유사한 특징을 나타내었다.

Cellulose 분해 균주인 GT21은 Gram 음성의 간균으로서 포자를 형성하지 못하였으며, 운동성을 나타내었다. Catalase test와 oxidase test에서 양성반응을 나타내었으며 lactose에서 는 산을 생성하지 못하였나 glucose, sucrose, xylose에서 산을 생성하였다. Gelatin을 잘 분해하였으며 VP test에서 음성을 나타내었고 nitrate reduction은 양성을 나타내었다. DNA 염 기성분인 $\mathrm{G}+\mathrm{C}$ 함량은 $61 \%$ 를 나타내어 Pseudomonas sp.의 $\mathrm{G}+\mathrm{C}$ 함량[23]과 거의 일치하였다. 이러한 결과를 바탕으로 분리균주 $\mathrm{KN} 11, \mathrm{KN} 13, \mathrm{KN} 27, \mathrm{GT} 21$ 은 각각 Acinetobacter sp., Neisseria sp., Bacillus sp., Pseudomonas sp.과 유사한 것으로 나타나 최종적으로 Acinetobacter sp. KN11, Neisseria sp. KN13, Bacillus sp. KN27, Pseudomonas sp. GT21로 명명하였다.

\section{복합 미생물제제의 제조 및 특성}

제지폐수에 대한 처리효율을 조사하기 위하여 유기물과 방 향족 화합물에 높은 분해능을 보이는 Acinetobacter sp. KN11, Neisseria sp. KN13, Bacillus sp. KN27 균주에 cellulose 분해활 성이 뛰어난 Pseudomonas sp. GT21을 첨가하여 제지폐수 처리 용 미생물제제를 제조하였다. 미생물제제 제조는 각 균주배양 액을 왕겨분말에 $4 \%$ 접종하고 영양액인 $0.5 \%$ yeast extract 용액을 $6 \%(\mathrm{v} / \mathrm{w})$ 로 첨가하였으며, $25 \%$ 내외의 수분함량을 유지하기 위하여 5 7일간 자연발효 및 건조를 병행하였다. 제제의 건조 후 $\mathrm{N}, \mathrm{P}$ 원과 무기영양원으로 $\mathrm{Ca}^{2+}, \mathrm{Fe}^{2+}$ 를 첨가 조합하였다. $\mathrm{Ca}^{2+}$ 는 알칼리도 충진의 목적으로, $\mathrm{Fe}^{2+}$ 는 미생 물의 흡착완화를 증진시키기 위해 $\mathrm{CaCl}_{2}$ 와 $\mathrm{FeSO}_{4}$ 의 형태로 조합시켰다. 무기염의 조합비율은 $\mathrm{AMP}, \mathrm{ADP}, \mathrm{CaCl}_{2}$ 와 $\mathrm{FeSO}_{4}$ 를 각각 1:1:0.2:0.5의 비율로 무게 비 $10 \%$ 로 첨가하였다. 정선 과정을 거친 후 제조된 미생물 제제는 미생물제제 J30으로 명 명하였으며 미생물제제 J30의 특성은 Table 2와 같다. 미생물 제제 $\mathrm{J} 30$ 의 경우 실온에서 50 일간 보존에서도 제조 초기의 생 균수와 큰 변화 없이 높은 균의 밀도를 유지하고 있었다.

\section{대상폐수의 성상}

제지폐수의 생물학적 처리효율을 조사하고, $\mathrm{COD}$ 증가의 원인 물질을 규명하기 위하여 J 제지공장 폐수처리장의 각 공 정별 원수, 1 차 처리수, 폭기조, 침전조, 방류수를 채취하여 $\mathrm{BOD}, \mathrm{COD}_{\mathrm{Mn}}, \mathrm{COD}_{\mathrm{Cr}}$, total oxygen concentration (TOC), T-N 및 T-P 성상을 분석하였다. Table 3과 같이 각 공정별 폐수의 
Table 1. Taxonomical properties of isolated strains

\begin{tabular}{|c|c|c|c|c|}
\hline \multirow{2}{*}{ Characteristics } & \multicolumn{4}{|c|}{ Strains } \\
\hline & KN11 & KN13 & KN27 & GT21 \\
\hline \multicolumn{5}{|l|}{ Morphological } \\
\hline Gram staining & - & - & + & - \\
\hline Shape & $\operatorname{rod}$ & cocci & $\operatorname{rod}$ & $\operatorname{rod}$ \\
\hline Size (cocci) & & 0.7 & & \\
\hline Size (width of rod) & $0.5 \sim 0.9$ & & $0.8 \sim 1.2$ & $0.7 \sim 0.9$ \\
\hline (length of rod) & $1.0 \sim 1.7$ & & $3.1 \sim 3.5$ & $1.4 \sim 2.7$ \\
\hline Spore & - & - & + & - \\
\hline Motility & + & - & + & + \\
\hline Acid fast & - & - & - & - \\
\hline \multicolumn{5}{|l|}{ Cultural } \\
\hline Colony color & yellow-milky & yellowish & milky-white & yellow-milky \\
\hline Growth in air & + & + & + & + \\
\hline Growth anaerobically & - & - & - & - \\
\hline Growth at $25^{\circ} \mathrm{C}$ & + & + & + & + \\
\hline Growth at $40^{\circ} \mathrm{C}$ & + & + & + & + \\
\hline Growth at $65^{\circ} \mathrm{C}$ & - & - & - & - \\
\hline Growth at $\mathrm{pH} 5.7$ & & + & - & \\
\hline Growth at $7 \% \mathrm{NaCl}$ & - & - & + & - \\
\hline \multicolumn{5}{|l|}{ Physiological } \\
\hline Catalase & + & + & + & + \\
\hline Oxidase & - & + & + & + \\
\hline $\mathrm{O} / \mathrm{F}$ (Oxidation/Fermentation) & $\mathrm{F}$ & $\mathrm{O}$ & $\mathrm{F}$ & $\mathrm{O}$ \\
\hline \multicolumn{5}{|l|}{ Carbohydrates, acid form } \\
\hline Glucose & - & + & + & + \\
\hline Lactose & - & - & + & - \\
\hline Sucrose & - & - & + & + \\
\hline Xylose & - & - & + & + \\
\hline \multicolumn{5}{|l|}{ Hydrolysis of } \\
\hline Gelatin & - & - & + & + \\
\hline Starch & - & - & + & - \\
\hline Voges-Proskuer reaction & - & - & - & - \\
\hline Nitrate reduction & - & + & + & + \\
\hline Indole reduction & + & - & + & - \\
\hline Urease & - & - & - & + \\
\hline \multicolumn{5}{|l|}{ Chemical } \\
\hline $\mathrm{Mol} \% \mathrm{G}+\mathrm{C}$ of DNA & 39 & 52 & 46 & 61 \\
\hline
\end{tabular}

Table 2. Characteristics of microbial augmentation, J30

\begin{tabular}{lc}
\hline Characteristics & Contents \\
\hline Total viable count & $1.8 \times 10^{10} \mathrm{CFU} / \mathrm{g}$ \\
Bulk density & 0.298 \\
Water content & $25.6 \%$ \\
Particle size & $50 \sim 100$ mesh \\
\hline
\end{tabular}

성상을 분석한 결과 원수에서 $\mathrm{COD}_{\mathrm{Mn}} \mathrm{COD}_{\mathrm{Cr}}$ 이 각각 1523 및 $2614 \mathrm{mg} / 1$ 로 매우 높은 수치를 나타내었다. 이것은 제지공장 의 폐수 발생원이 생산 공정뿐만 아니라 원료의 재생 및 가공 공정에서 발생되는 폐수가 함께 유입되어 폐수의 발생량 또한 많았던 것이 원인으로 생각되었다. BOD 제거 효율을 조사한
결과, 화학침전 1 차 처리조에서는 유입수인 원수에 대해 $76.3 \%$ 의 비교적 높은 처리효율을 보였다. 폭기조의 생물학적 처리조에서는 원수에 대해 $44.4 \%$, 침전조에서는 $71.3 \%$, 방류 수에서는 $78.9 \%$ 로 처리가 잘 되는 것으로 조사되었다. 폭기조 에서의 원수에 대한 처리효율 감소는 폭기에 의한 $\mathrm{BOD}$ 증가 로 인해 제거효율이 감소된 것으로 생각되었다.

\section{호흡률 조사}

폐수 처리장내의 원수, 1 차 처리수 및 폭기조 세 지점에서 채수한 폐수를 대상으로 미생물에 미치는 독성 영향을 평가하 기 위하여 호흡률을 조사한 결과(Table 4), 활성오니를 기준으 로 1 차 처리수와 원수의 산소 소비율 및 상대 호흡률이 감소하 
Table 3. Characteristics of a paper mill wastewater

(unit: $\mathrm{mg} / \mathrm{l}$ )

\begin{tabular}{lcccccc}
\hline Wastewater & BOD & COD $_{\text {Mn }}$ & COD $_{\text {cr }}$ & TOC & T-N & T-P \\
\hline Influent & 93.78 & 1523.0 & 2614.0 & 1130.4 & 63.214 & 1.374 \\
Chemical treatment & 21.25 & 372.5 & 672.3 & 283.2 & 5.017 & 0.674 \\
Aeration tank & 52.12 & 96.5 & 162.1 & 61.3 & 16.318 & 3.142 \\
Sediment tank & 29.62 & 76.2 & 145.4 & 52.4 & 14.156 & 1.769 \\
Effluent & 19.73 & 73.5 & 121.3 & 43.7 & 13.175 & 1.385 \\
\hline
\end{tabular}

Table 4. Respiratory rate of a paper mill wastewater

\begin{tabular}{lcc}
\hline Wastewater & $\begin{array}{c}\text { Oxygen consumption } \\
\text { rate }(\triangle \mathrm{DO})\end{array}$ & $\begin{array}{c}\text { Relative } \\
\text { respiration rate }\end{array}$ \\
\hline Influent & $0.87 \pm 0.02$ & 0.32 \\
Chemical treatment & $1.59 \pm 0.01$ & 0.71 \\
Activated sludge & $2.41 \pm 0.06$ & 1.00 \\
\hline
\end{tabular}

는 것으로 나타났다. 산소 소비량이 증가하는 것은 미생물의 호흡이 빨라지고 유기원의 부하가 증가하는 것을 의미하며, 상대 호흡률의 감소는 폐수 내의 물질 중 미생물 호흡을 방해 하는 물질을 내포하고 있는 것으로 심할 경우 폭기조 미생물 에 독성을 유발하는 것으로 보고되었다[11].

\section{$\mathrm{GC} / \mathrm{MS}$ 분석}

제지폐수 중 난분해성 물질의 유도산물 및 $\mathrm{COD}$ 증가의 원 인 물질을 분석하기 위하여 $\mathrm{GC} / \mathrm{MS}$ 를 이용하여 분석한 결과 (data not shown), 리그닌과 같은 난분해성 물질의 유도산물 인 벤젠 고리를 가진 방향족 탄화수소와 벤젠 고리에 여러 가지 작용기 및 할로겐 원자 등으로 치환된 방향족 탄화수소 의 유도체를 관찰하였다. 리그닌과 같은 난분해성 물질이 산 화되면 그 내부 구조인 벤젠 구조 자체가 파괴되는 것이 아니 라 중합 구조의 연결 고리가 파괴되거나 증가되어 더욱 안정 된 물질로 변화하므로 일반적인 미생물에 의해서 분해되기 어렵다[10,14,25]. 제지 공장의 폐수처리장 내에 유입되는 난분 해성 물질이 고분자 형태의 물질로 존재하는 것으로 알려져 있지만, 각 폐수 공정별 처리를 통해 폐수 내에 존재하는 난분 해성 물질은 고분자가 아닌 유도산물로 전환되는 것으로 판단 되었다. 이는 유도산물을 효율적으로 분해할 수 있는 적정 미 생물의 탐색 및 선별을 통하여 제지폐수의 생물학적 처리효율 을 높일 수 있는 것으로 생각된다.

\section{배양조건 및 배양시간에 따른 $\mathrm{COD}$ 감소효율}

제지폐수의 효율적 처리를 위하여 선별된 4 균주로 구성된 미생물제제 $\mathrm{J} 30$ 의 플라스크 수준에서 $\mathrm{COD}$ 감소효율 최적화 를 위하여 온도, $\mathrm{pH}$ 및 배양시간에 따른 균체 성장을 조사하였 다. 온도 변화에 따른 $\mathrm{COD}$ 감소효율은 $25^{\circ} \mathrm{C}$ 이후 급격히 증가 하여 분리균주는 $28 \sim 30^{\circ} \mathrm{C}$ 에서 약 $70 \%$ 의 제거효율을 나타내 었으며 미생물제제 $\mathrm{J} 30$ 은 처리온도 $30^{\circ} \mathrm{C}$ 에서 $82 \%$ 의 효율을 나타내었다(data not shown). 처리 온도 $30^{\circ} \mathrm{C}$ 에서 $\mathrm{pH}$ 에 따른
$\mathrm{COD}$ 감소 효율을 조사한 결과 Fig. 1에 나타난 바와 같이 분리 균주는 $\mathrm{pH} 7.0 \sim 8.0$ 의 범위에서 $73 \%$ 의 효율을 보였으며, 미생 물제제 $\mathrm{J} 30$ 의 경우 $\mathrm{pH} 7.5$ 에서 $87 \%$ 의 감소율을 나타내었다.

배양시간에 따른 $\mathrm{COD}$ 제거효율은 미생물제제 $\mathrm{J} 30$ 의 경우 배양 60 시간에서 감소효율 $90 \%$ 로 최대를 나타내었다(Fig. 2).

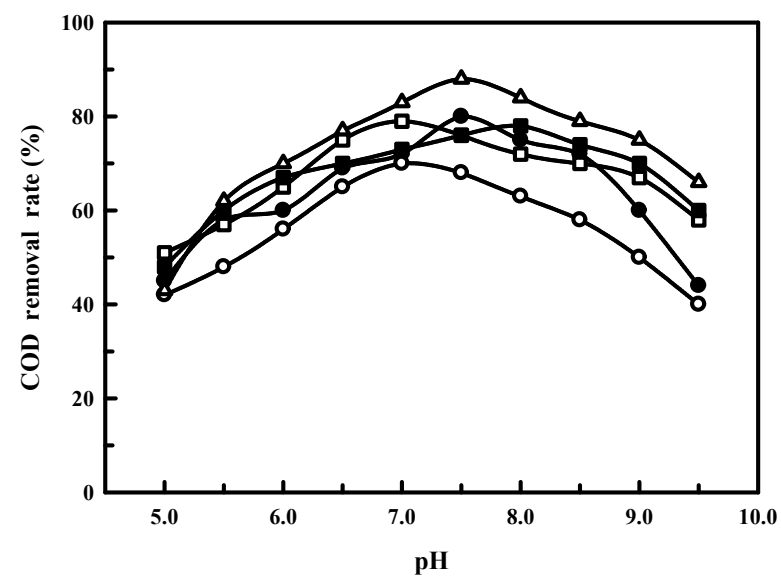

Fig. 1. Effect of $\mathrm{pH}$ on the efficiency of COD removal in paper mill wastewater. The symbols; $\bigcirc$ : Psedomonas sp. GT21, -: Acinetobacter sp. KN11, $\square$ : Neisseria sp. KN13, Bacillus sp. KN27, $\triangle$ : microbial augmentation, J30.

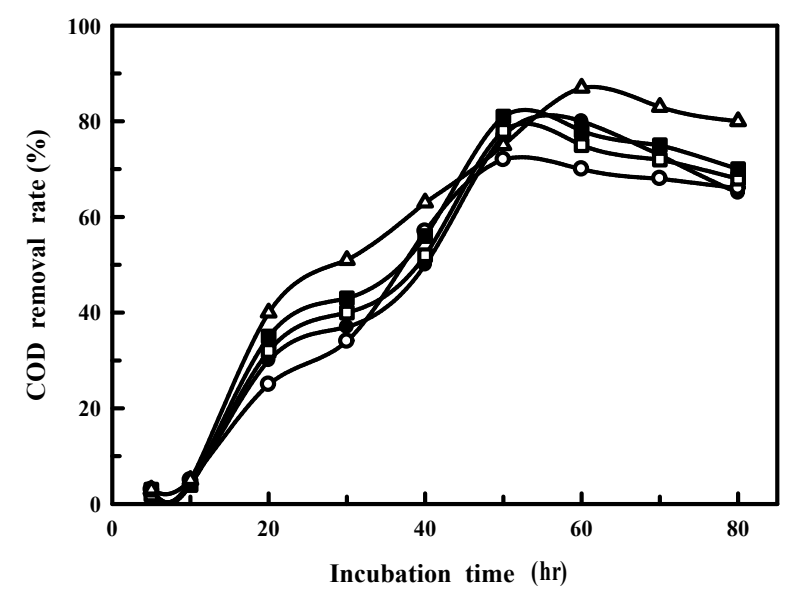

Fig. 2. Effect of incubation time on the efficiency of COD removal in paper mill wastewater. The symbols; $O$ : Psedomonas sp. GT21, •: Acinetobacter sp. KN11, $\square$ : Neisseria sp. KN13, घ: Bacillus sp. KN27, $\triangle$ : microbial augmentation, J30. 
이상의 결과에서 단일 균주는 약 $70 ~ 80 \%$ 감소효율을 나타낸 데 비하여 미생물제제 $\mathrm{J} 30$ 처리구에서는 약 $10 \sim 20 \%$ 정도의 상승효과를 나타내었다. 따라서 제지폐수의 효율적인 처리를 위해서는 혼합균주인 미생물제제 $\mathrm{J} 30$ 을 이용하였을 때 COD 처리효율을 극대화할 수 있는 것으로 파악되었다.

\section{미생물제제를 이용한 실험실 규모의 pilot test}

제지폐수처리 시험은 실험실 규모의 아크릴 반응조(2 l)에 서 미생물제제 $\mathrm{J} 30$ 의 COD 제거효율을 검토하기 위하여 연속 실험을 진행하였다. 제지 1차 처리수는 체류시간 $48 \mathrm{hr}$ 로 초기 조정하여 미생물제제 J30 처리구와 기존 현장의 활성오니를 대조구로 하여 처리효율 시험을 수행하였다. 시험 전 2일간 활성오니를 공폭기하여 제지폐수에 충분히 순양하도록 적응 기간을 두었고 미생물제제 J30의 접종량은 초기 $200 \mathrm{mg} / 1$ 를 투여하고, 안정화 기간 동안 매일 $100 \mathrm{mg} / 1$ 씩 투여하였으며 안정화 이후 $50 \mathrm{mg} / 1$ 를 투여하였다.

두개의 pilot을 대조구와 실험구로 하여 미생물 제제 J30의 투입 전 10 일 동안 유입수(1차 처리 수)와 유출수(처리된 폭기 조 물)의 COD 변화와 미생물제제 J30 투입 후 10 일간의 변화 를 조사한 결과(Fig. 3), 미생물제제 투입 전 대조구의 COD 제거율은 $71 \%$ 로 나타났으며, 미생물제제 $\mathrm{J} 30$ 의 투입 후 평균 $\mathrm{COD}$ 제거효율은 $87 \%$ 로 약 $16 \%$ 상승한 것으로 조사되었다. 시험기간 동안 $\mathrm{pH}$ (data not shown)는 대조구에서 운전 3일째 부터 감소하기 시작하여 처리 5일째 이후 약산성 영역으로 유지되었다. 이는 $\mathrm{COD}$ 감소와 비교할 때 미생물의 활발한 증식활동에 의하여 생산되는 대사산물, 즉 유기산의 영향에 기인하는 것으로 생각된다.

유용균주의 혼합체로서 개발된 미생물제제 J30은 안정성 연구와 현장적응 과정을 거쳐 사용할 경우 제지산업폐수의 효율적인 생물학적 처리가 가능할 것으로 판단된다.

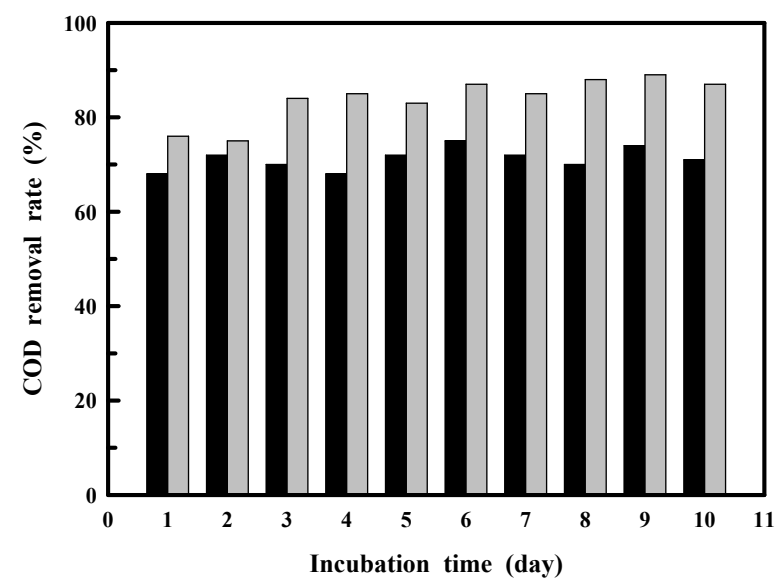

Fig. 3. Bench scale pilot test of paper mill wastewater. Treatment of paper mill wastewater was done at $25^{\circ} \mathrm{C}, \mathrm{pH} 7.5$ for 10 days on bench scale pilot. The symbols; $\mathbf{\square}$ : activated sludge (control), $\square$ : microbial augmentation, J30.

\section{감사의 글}

본 연구는 2009년 국립 경남과학기술대학교 기성회의 연구 비 지원을 받아 수행되었습니다.

\section{References}

1. Alfonso, M. D. 1992. Nanofiltration removal of chlorinated organic compounds from alkaline bleaching effluents in a pulp and paper plant. Water Res. 26, 1639-1643.

2. Ascon-Cabrera, M. and J. M. Lebeault. 1993. Selection of xenobiotic-degrading microorganisms in a biphasic aqueous system. Appl. Environ. Microbiol. 59, 1717-1724.

3. Ambujom, S. and V. B. Manital. 1995. Phenol degradation by a stable aerobic consortium and its bacterial isolates. Biotechnol. Lett. 17, 443-448.

4. APHA, AWWA, and WEF. 1992. Standard methods for the examination of water and wastewater. 18th eds., APHA, Washington.

5. Babrock, R. W. Jr. 1991. Enricher-reactor bioaugmentation of activated sludge for degradation of hazardous wastewater. Ph. D. thesis, Univ. Calif. Los Angeles, California.

6. Babrock, R. W., Jr. K. S. Ro, C. C. Hsieh, and M. K. Stenstorm. 1992. Development of an off-line enricher-reactor process for activated sludge degradation of hazardous wastes. Water Environ. Res. 64, 782-791.

7. Barnard, J. L. 1972. Biological nutrient removal without the addition of chemicals. Water Res. 9, 485-493.

8. Cowan, N. R. and K. J. Steel. 1974. Manual for the identification bacteria. 2nd eds., Cambridge University, London.

9. Katayama, T., F. Nakatsubo, and T. Higuchi. 1986. Degradation of a phenyl coumarin, a lignin substructure model by Fusarium solani M-13-1. Mokuzai Gakkaichi 32, 535-544.

10. Kim, M. G. and W. Y. Ahn. 1998. Biodegradation of kraft lignins by white rot fungi-lignin from pitch pine. J. Korean Eng. 17, 156-170.

11. Kim, G. H. 1991. Study on COD removal and environmental regulations of paper mill wastewater. pp. 143-151. Vol. 16, Civil and Environmental Institute, Chonbuk National University, Jeonju.

12. Komagata, K. and K. I. Suzuki. 1987. Lipid and cell-wall analysis in bacterial systematics, pp. 161-207, In Colwell, R. R. and R. Grigorova (eds.), Methods in Microbiology. Vol. 19, Academic Press, London.

13. Ko, Y. H., I. H. Ha, and K. S. Bae. 1988. Isolation and Characterization of a naphthalene-degrading strain, Pseudomonas putida N3. Korean J. Appl. Microbiol. Biotechnol. 16, 199-204.

14. Lee, W. S., S. W. Jung, C. S. Park, B. D. Yoon, J. E. Kim, and H. M. Oh. 2001. Biological treatment of wastewater containing chlorinated phenols by a mixed culture. Korean J. Appl. Microbiol. Biotechnol. 29, 115-120. 
15. Legrini, O., E. Oliveris, and A. M. Braun. 1993. Photochemical process for water treatment. Chem Rev. 93, 671-674.

16. MacFaddin, J. F. 1984. Biochemical tests for identification for medical bacteria. 2nd eds,. Williams \& Wilkins Co., Baltimore, Maryland.

17. Orhon, D. 1992. The effect of residual COD on the biological treatability of textile wastewater. Water Sci. Technol. 26, 815-822.

18. Otte, M. P., J. Gagnon, Y. Comeau, N. Matte, C. Greer, and R. Sampson. 1994. Activation of an indigenous microbial consortium for bioaugmentation of pentachlorophenol/ creosote contaminated soils. Appl. Microbiol. Biotechnol. 40, 926-932.

19. Pan, B. and L. Hartmann. 1992. Activity of biomass in RBC system treating pulp Industrial wastewater. J. Environ. Eng. 118, 744-754.

20. Peter, H. A. S., S. M. Nicholas, M. E. Sharpe, and J. F. Holt. 1986. Bergey's manual of systematic bacteriology, Williams and Wikins Co., Baltimore, Maryland.

21. Pfral, C., G. Ditzelmuller, M. Loidl, and F. Streichsbier. 1990. Microbial degredation of xenobiotic compounds. FEMS
Microbiol. Ecol. 73, 255-262.

22. Son, Y. J., O. J. Sul, D. K. Chung, I. S. Han, Y. J. Choi, and C. S. Jeong. 1997. Isolation and Characterization of Trichoderma sp. C-4 producing cellulases. Korean J. Appl. Microbiol. Biotechnol. 25, 346-353.

23. Stanbury, P. F. and A. Whitaker. 1984. The isolation, preservation and improvement of Industrial microorganisms. pp. 26-73, In Whitaker, A. and P. F. Stanbury (eds.), Principles of Fermentation Technology. Pergamon Press, Oxford.

24. Tamaoka, K. and K. Komagata. 1984. Determination of DNA base composition by reversed-phase high-performance liquid chromatography. FEMS Microbiol. Lett. 25, 125-128.

25. Vaishnav, D. D. and E. Korthals. 1989. Effect of microbial concentration on biodegradation rates of phenols. J. Ind Microbiol. 4, 307-314.

26. Wood, P. J., J. D., Erfle. and R. M. Teather. 1988. Use of complex formation between Congo Red and polysaccharides in detection and assay of polysaccharide hydrolases. pp. 63-65, In Wood, E. A. and S. T. Kelloge (eds.), Method in Enzymology. Vol. 160, Academic Press, Orlando, Florida.

\section{초록 : 제지폐수 처리용 미생물의 분리 및 복합 미생물제제의 개발 \\ 강대욱 ${ }^{2} \cdot$ 서현효 $^{1}$ * \\ ( ${ }^{1}$ 국립경남과학기술대학교 환경공학과, ${ }^{2}$ 국립창원 대학교 보건의과학과)}

제지폐수의 효율적인 생물학적 처리와 폐수특성에 적합한 미생물제제의 개발을 위하여 토양 및 산업폐수로부 터 방향족 화합물에 분해활성이 높은 KN11, KN13 및 KN27 균주와 세포 외 섬유소 가수분해효소 생산 균주 GT21 등의 균주를 분리하였다. 형태학적, 생리학적 및 생화학적 분류를 통해 이들 분리주 KN11, KN13, KN27 및 GT21 등은 Acinetobacter sp., Neisseria sp., Bacillus sp., Pseudomonas sp.와 유사한 것으로 판명되어 최종적으로 각각 Acinetobacter sp. KN11, Neisseria sp. KN13, Bacillus sp. KN27, Pseudomonas sp. GT21로 명명하였다. 제지폐 수 중 난분해성 물질과 $\mathrm{COD}$ 증가원인 물질을 분석하고자 $\mathrm{GC} / \mathrm{MS}$ 를 이용하여 방향족 화합물 및 그 유도체들을 검출하였다. 분리균주 Acinetobacter sp. KN11, Neisseria sp. KN13, Bacillus sp. KN27 및 Pseudomonas sp. GT21의 균체로 구성된 미생물제제 J30을 제조하여 제지폐수의 효율적 처리를 위한 연구에 사용하였다. 미생물제제 J30의 제지폐수에서 $\mathrm{COD}$ 제거를 위한 최적온도와 $\mathrm{pH}$ 는 각각 $30^{\circ} \mathrm{C}$ 와 7.5 였으며 배양 60 시간에서 최대의 $\mathrm{COD}$ 제거효 율을 나타내었다. 실험실 규모의 pilot plant에서 미생물제제 J30의 COD 제거효율은 $87 \%$ 의 높은 제거효율을 나 타내었다. 